
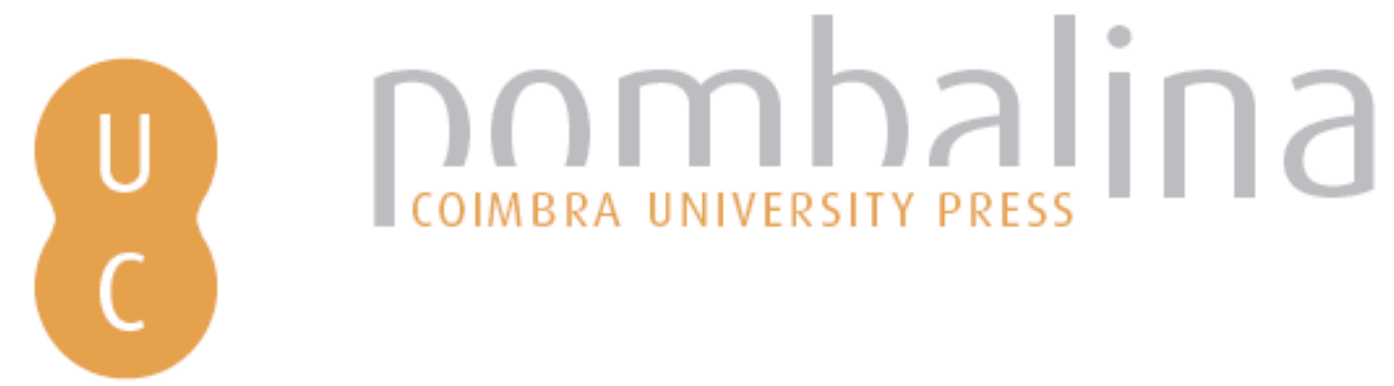

\title{
Reading and writing the game: tactical skills in team sports
}

Autor(es): $\quad$ Elferink-Gemser, Marije T; Kannekens, Rianne; Huijgen, Barbara; Tromp, Yvonne; Jonker, Laura; Toering, Tynke; Visscher, Chris

Publicado por: Imprensa da Universidade de Coimbra

URL persistente:

URI:http://hdl.handle.net/10316.2/31710

DOI:

DOI:http://dx.doi.org/10.14195/978-989-26-0506-7_11

Accessed : $\quad$ 26-Apr-2023 14:33:06

A navegação consulta e descarregamento dos títulos inseridos nas Bibliotecas Digitais UC Digitalis, UC Pombalina e UC Impactum, pressupõem a aceitação plena e sem reservas dos Termos e Condições de Uso destas Bibliotecas Digitais, disponíveis em https://digitalis.uc.pt/pt-pt/termos.

Conforme exposto nos referidos Termos e Condições de Uso, o descarregamento de títulos de acesso restrito requer uma licença válida de autorização devendo o utilizador aceder ao(s) documento(s) a partir de um endereço de IP da instituição detentora da supramencionada licença.

Ao utilizador é apenas permitido o descarregamento para uso pessoal, pelo que o emprego do(s) título(s) descarregado(s) para outro fim, designadamente comercial, carece de autorização do respetivo autor ou editor da obra.

Na medida em que todas as obras da UC Digitalis se encontram protegidas pelo Código do Direito de Autor e Direitos Conexos e demais legislação aplicável, toda a cópia, parcial ou total, deste documento, nos casos em que é legalmente admitida, deverá conter ou fazer-se acompanhar por este aviso. 
Manuel J. Coelho e Silva António J. Figueiredo Marije T. Elferink-Gemser Robert M. Malina Editors
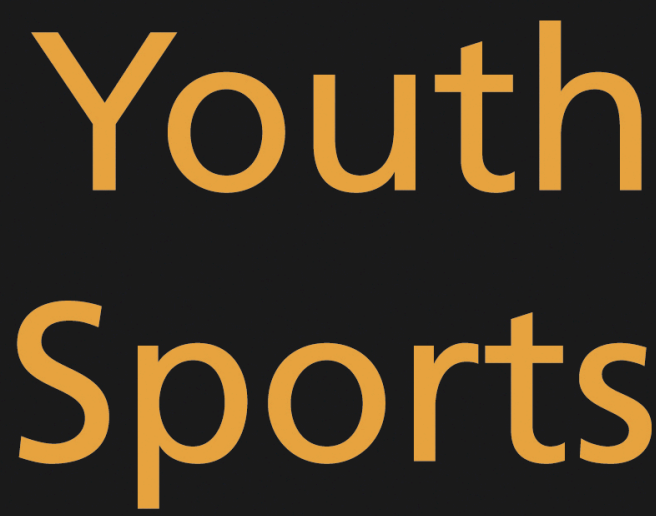

\section{Growth, Maturation and Talent}




\title{
EDIC̣̃̃o
}

Imprensa da Universidade de Coimbra

Email: imprensauc@ci.uc.pt

URL: http://www.uc.pt/imprensa_uc

Vendas online: http://www.livrariadaimprensa.com

\section{CONCEPÇÃO GRÁFICA}

António Barros

\section{EXECUÇÃO GRÁFICA}

\author{
Norprint
}

ISBN

978-989-26-0005-5

\section{DEPÓSITO LEGAL}


Manuel J. Coelho e Silva António J. Figueiredo Marije T. Elferink-Gemser

Robert M. Malina

Editors
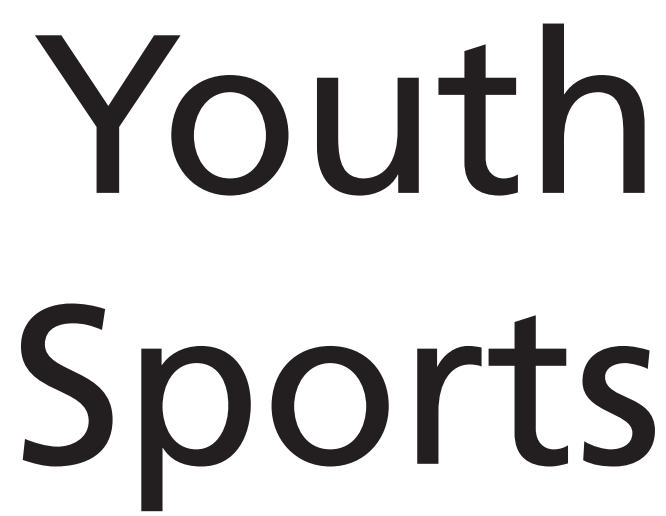

Growth, Maturation and Talent

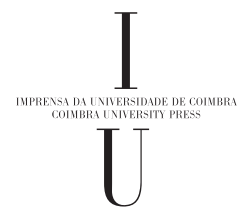


Part 3:

TRAINING 


\title{
CHAPTER II: READING AND WRITING THE GAME: TACTICAL SKILLS IN TEAM SPORTS
}

\author{
Marije T Elferink-Gemser \\ Rianne Kannekens \\ Barbara Huijgen \\ Yvonne Tromp \\ Laura Jonker \\ Tynke Toering \\ Chris Visscher
}

\section{INTRODUCTION}

Several team sports can be categorized as invasion sports, in which players compete at the same field of action as their opponents. The sports are time dependent and can be sub-categorized into goal-throwing (e.g., basketball), try scoring (e.g., rugby), and goal-striking games (e.g., soccer, field hockey). They are characterized by the need for players to constantly adapt to opposition by rapid adaptation to changing play configurations and to the movement of the ball. In such games, players have to deal with a complex and rapidly changing environment while invading the opposing team's area of the field in order to score (Almond, 1986; Hughes and Bartlett, 2002; Williams, 2000). Success requires that players of all ages have well-developed physiological and technical characteristics in addition to cognitive skills as well (French and Thomas, 1987; Helsen and Starkes, 1999; Nougier and Rossi, 1999; Starkes, 1987; Williams et al., 1993). The integration of physical, technical and cognitive skills is generally apparent in studies showing that many talented athletes not only perform well in sports but also in school settings (Jonker et al., 2009).

Playing at a high level of performance in invasion sports means choosing the right action at the right moment and performing that course of action efficiently and consistently throughout the match (Baker et al., 2003a; Gréhaigne et al., 200 I). To perform the right action at the right moment, with a successful performance or outcome, proper understanding of the game is necessary. Reading the game and reacting in parallel can therefore be viewed as a key characteristic for high level of performance. However, what is the meaning of reading the game properly and reacting at the same time with the appropriate action? A number of terms have been used to describe successful performance, for example, game intelligence, implicit knowledge, tricks of the trade, practical intelligence, tactics, tactical knowledge and tactical skills (Bjurwill, 
1993; Gréhaigne and Godbout, 1995; Gréhaigne et al., 1999; McPherson, 1994). The term tactical skills is the presently utilized label (McPherson and Kernodle, 2003). Tactical skills are cognitive skills and are different from, but tightly coupled to strategy. Both, tactical skills and strategy are needed to read the game and execute the right action at the right moment. Tactical skills refer more to 'the decision-making activity during the game and to the knowledge about adaptations in action' in contrast to strategy which refers to 'knowledge about programming' or 'planning' (Bjurwill, 1993; Mouchet, 2005). In other words, tactical skills relate to the quality of an individual player to perform the right action at the right moment and should therefore be distinguished from strategy, which relates to choices discussed in advance with the trainer in order for the team to organize itself (Gréhaigne and Godbout, 1995).

McPherson and Thomas (1989) predicted that the type of cognitive processes of athletes during competition could be linked to their knowledge base of the task. Knowledge structure of sports can be defined as "knowledge of the game's goal structure combined with knowledge of related game events in terms of the game's goal structure'. This means that sport knowledge may not only refer to the decisions concerning the appropriate action in the context of the game situation ("if-then"), but also to the ability to execute the complex sport skill ("do") (McPherson and Thomas, 1989). These two important sources of knowledge are also defined as declarative ("knowing what to do") and procedural ("really doing it") knowledge and are the basis of tactical skills.

Distinguishing between on-the-ball and off-the-ball situations is one way to categorize elements of tactical skills related to the nature of match play in invasion games (Oslin et al., 1998). On-the-ball actions refer to attacking, situations where the team is in possession of the ball and tries to score. Offthe-ball actions refer to defense, preventing the opposing team from scoring. Tactical skills related to attack can thus be distinguished from those related to defense (Bjurwill, 1993). Tactical skills are similar across invasion games, such as maintaining possession of the ball, attacking the goal, and creating space in the attack, as are defending space or defending against an attack (Mitchell, 1996).

\section{TACTICAL SKILLS AND TECHNIQUE}

There is a difference between response selection and response execution in sports compared to response selection and execution in other domains (e.g., chess, computer language). In sports, tactical skills not only involve the ability to determine which decision is most appropriate in a given situation, but also involve decisions whether the decision can be successfully executed within the constraints of the required movement. In invasion sports, these constraints are largely physiological and technical, and limit the tactical options available to the 
athlete (Janelle and Hillman, 2003). Although athletes are free to circulate between plan (strategy) and tactical adaptation, this freedom is influenced by personal characteristics and the game circumstances (Mouchet, 2005).

Physiological and technical skills improve during adolescence (ElferinkGemser et al., 2006; Huijgen et al., 2009; Visscher et al., 2006). Speed, power and other functional capacities improve (Baxter-Jones et al., 1993; Hansen et al., 1999) and together with the development of intellectual and motor skills lead to improved technical abilities (Gil et al., 2007). Invasion sports require a combination of physiological, technical, psychological and tactical skills for good performance (Elferink-Gemser et al., 2004; 2007). Evidence indicate increased sprinting performance and technical proficiency in dribbling performance in talented youth soccer players during adolescence (Huijgen et al., 2009; Kukolj et al., 2003; Gil et al., 2007; Vaeyens et al., 2006). These improved abilities permit additional tactical options for players (Visscher et al., 2005). Therefore, good physiological and technical skills provide more choices available for players and the ability to execute the actions more quickly and proficiently. To be an outstanding player, correct technique needs to be selected and performed as determined by the demands of the situation (Ali et al., 2007).

\section{TACTICAL SKILLS AND LEVEL OF PERFORMANCE}

The relation between tactical skills and performance has been examined by many researchers. Due to more highly developed tactical skills, expert athletes are better able to select the appropriate response for a situation within the context of the game's goal structure, based on less information, and can do so more quickly than novice athletes (Thomas et al., 1986; Williams et al., 1993). It is suggested that the difference between experts and novices is that experts can 'read the game' quicker and more accurately than novices (Baker et al., 2003b). Tactical skills are thus an important attribute of expertise. It is also suggested that the level of knowledge structure of a sport situation and an individuals' knowledge of 'what to do' affects the quality of decision(s) made in the context of a game situation, and the quality of decisions made within the context of the game are the best discriminators between expert and novice children regardless of age (French and Thomas, 1987).

The contribution of basketball knowledge (declarative) and specific basketball skills (procedural) to the development of skilled decision-making and overall basketball performance was studied in groups of high- and lowskilled youth 8-10 and II-12 years of age (French and Thomas, 1987). Highly skilled basketball players possessed more basketball knowledge and scored higher on specific basketball skills. To clarify the content and structure of knowledge used in tactical skills, knowledge structures of male youth tennis players $10-11$ and $12-13$ years was examined using a verbal report instrument 
(McPherson and Thomas, 1989). Results suggested that the content of an experts' knowledge compared to players of a lower level consisted of concepts that were more complex.

To date, research into the relationship between tactical skills and performance or competitive levels has been restricted largely to identifying expert-novice differences. The studies all show that expert athletes outscore novice athletes on many aspects of tactical skills. Experts have an extensive and rich domain-specific knowledge structure due to the development of an enhanced declarative knowledge base and a well-developed procedural knowledge base. The knowledge structures of experts consist of representations in which the concepts are more varied, complex and interrelated. Furthermore, experts have highly evolved problem representations that contain well-developed action plans and current event profiles. In contrast, the novice performers have a limited amount of domainspecific knowledge, generate more single concepts which are less interrelated, and use rudimentary goals or at best have access to rudimentary action plan profiles (French et al., 1996; Starkes, 1987; Williams and Davids 1995) .

Although valuable, the studies indicate relatively little on how the best can be distinguished from good players, which is a prerequisite in the field of talent development. In a recent study on tactical skills of world-class youth soccer teams, differences in highly experienced players were not as apparent as differences between experts and novices, although within an elite team the best players had different performance profiles than the 'lesser' players on their team (Kannekens et al., 2009). It was concluded that tactical skills were fundamental to high-level soccer performance. Talented youth players also outscored regional youth players on both declarative and procedural tactical skills (Visscher et al., 2005). Talented players knew better what to do during games and also better performed the proper action at the right moment. With increasing levels of performance, i.e., within a group of talented players, elite youth players outscored sub-elite youth players on procedural knowledge, but not on declarative knowledge. In other words, sub-elite youth players know what to do equally as well as elite youth players. However, when it comes to performing the right action at the right moment with opponents limiting space and time available, the elite players outscore their sub-elite counterparts.

\section{MEASURING TACTICAL SKILLS}

To measure the interaction between declarative and procedural knowledge within the sports domain, it is very important to have an instrument that can differentiate players' response selection and execution during actual competition. One of the developed instruments to examine the 
representation of conceptional knowledge (e.g., declarative and procedural knowledge) and to examine how this knowledge guides the solution process during problem solving or task performance, is a verbal report instrument (McPherson, 1994; McPherson and Thomas, 1989). Using verbal report procedures, athletes must verbalize the area of the display, which they consider particularly informative. Data can be collected either concurrently, during or retrospectively following completion of the performance. Consequently, a more direct measure of attentional allocation and information extraction is provided, leading to more insight in which information the athletes attend to and how they use it (Ericsson and Simon, 1980; Williams et al., 1999).

To clarify issues regarding sport-specific knowledge bases, a coding system makes it possible to code responses in the verbal reports into concepts. A concept was defined as 'a unit of information about response selection in the context of a game situation' (McPherson and Thomas, 1989). Three different concepts are used to examine the knowledge bases: condition, action or goal concepts. Condition concepts are 'abstract concepts specifying when and under which conditions to apply the action or patterns of action to achieve the goal'. Action concepts refer to 'the action selected or patterns of action selected which produces goal related changes in the context of a game situation'. Goal concepts are 'the game's goal structure usually hierarchically organized'. By coding these concepts, the content and structure of knowledge in tactical skills can be determined. The content of knowledge can be assessed by the information stored, which in turn can be measured by the total number of concepts, total number of different concepts, and quality of each concept. The goal, action and condition concepts interact and the structure of knowledge can be measured by the frequency of connections between concepts and the units (linkage) of concepts (McPherson and Thomas, 1989).

In addition to the coding system, a memory model was introduced (French and McPherson, 1999). The model suggests that the knowledge base for sports includes declarative and procedural knowledge (for both response selection and execution) and also other sport-specific memory adaptations and structures. The model depicts two specialized memory adaptations in long-term memory, termed action plan profiles and current event profiles. The former are 'rule-governed prototypes stored in long-term memory used to match certain current conditions with appropriate visual and/or motor actions'. These conditions are typically explicit environmental cues (i.e., player location) or general game strategies (i.e., tennis player being taught to rush to the net on a short shot). Current event profiles are 'tactical scripts that guide constant building and modifying of pertinent concepts (past, current, and/or future) to monitor during the competitive event' (French and McPherson, 1999). The current event profile is built upon past competitions and from specialized 
monitoring, encoding, and retrieval processes that are used to collect information throughout the current competition. To form a complete current representation of the game, both profiles are needed. The action plan and current event profiles were introduced to illustrate differences in levels of processing during sport competition.

Although there are several ways to assess tactical skills, there is to date no standard measure. Cognitive psychologists have used propositional-type analyses of subjects' think-aloud protocols whereas others measured tactical skills with picture or film slides of game situations (Allard and Burnett, 1985; Allard et al., 1993; Chamberlain and Coelho, 1993), by using the opinion of expert coaches, or through self-assessment (Elferink-Gemser et al., 2004). Most studies assessing tactical skills in experimental test situations in a laboratory setting had subjects view action sequences on a video projection screen (Bard et al., 1994; Helsen and Starkes, 1999; McMorris and Graydon, 1997; Williams et al., 1993). This design, however, does not account for the fact that response execution affects response selection since the athletes were only required to state which decision they thought was correct (response selection); they were not required to execute it (response execution).

Even though these settings are useful for fundamental research, they are less suitable for applied purposes. For example, laboratory studies are different from the real-world settings in which a player has to deal with the pressure of opponents, time constraints, and stress (McPherson and Kernodle, 2003). In the field, there is a clear need for information about the tactical skills of individual players, for instance, to help trainers guide youth players toward a higher performance level. Information on tactical skills could also prove to be very valuable in leading talented players to the top or in evaluating training effects. A measurement that is specifically designed for application in sports practice and that takes real-world settings into account is the Tactical Skills Inventory for Sports (TACSIS, Elferink-Gemser et al., 2004). Whether the inventory is capable of measuring the whole concept of tactical skills cannot completely be ascertained without an accepted reference instrument. Yet, this instrument was constructed with the help of expert trainers and was embedded in theory. This method of gathering items can be considered logical validity, also referred to as face validity, and supports the notion that the TACSIS is really measuring tactical skills (Thomas and Nelson, 1996).

\section{THE TACSIS}

The Tactical Skills Inventory for Sports (TACSIS) includes four subscales: knowing about ball actions, knowing about others, positioning and deciding, and acting in changing situations. To construct the self-reporting inventory, the theoretical elements on tactical skills according to the framework created by 
McPherson (1994) were discussed with nineteen highly qualified trainers of youth national and district selection invasion sports teams in the Netherlands (soccer and field hockey). The framework consists of continuums that move from response selection to response execution and from knowledge (knowing what to do) to action (doing it) in addition to the distinction between attacking versus defensive situations. The trainers were asked to put forward those elements they considered most important for high performance (Elferink-Gemser et al., 2004). Questions were formulated and reformulated until consensus was reached within the team of experts on the content of the inventory. Thirty-four items regarding sports performance were put in questionnaire form using a 6-point Likert scale, ranging from 'very poor' to 'excellent' or from 'almost never' to 'always'. To provide players with an external reference the players are required to compare themselves with the top in their age category. As a consequence, all players are provided with a reference point relating to their age category.

To examine the structure of relations among items in the original sample for the purpose of bringing them together into a smaller set of variables or constructs (Nunnally and Bernstein, 1994), a factor analysis was conducted using a sample of 209 youth players (I5.8 1.6 years, range 12.6I 8.9 years), all participants in competitive field hockey $(n=123)$ or soccer $(n=86)$. Principal component analysis with the four factors fixed followed by varimax rotation yielded a structure which accounted for $50 \%$ of the response variance. Twenty-two items met the criterion of having a factor loading greater than or equal to 0.55 (Elferink-Gemser et al., 2004). Items of the TACSIS are presented in Table I.

The scale for knowing about ball actions contains four items related to declarative knowledge of attacking situations, an example of which reads: 'I know exactly when to pass the ball to a teammate or when not to'. The five items of the scale for knowing about others address declarative knowledge of defensive situations (e.g., 'I know quickly how the opponent is playing'). Positioning and deciding has nine items on procedural knowledge of attacking situations (e.g., 'my getting open and choosing positions is'). The four items of scale for acting in changing situations gauge procedural knowledge of defensive situations (e.g., 'my interception of the opponent's ball is'). By testing the four key elements of tactical skills, i.e., declarative versus procedural and attacking versus defensive situations, the TACSIS captures all four aspects of tactical skills.

The TACSIS has been shown to have good psychometric characteristics with internal consistency coefficients (Cronbach's alphas) of all four subscales ranging from 0.72 to 0.89 (Elferink-Gemser et al., 2004). The intraclass correlation coefficients for repeated measures were as follows: 0.76 
for knowing about others, 0.88 for positioning and deciding, 0.82 for acting in changing situations, and 0.60 for knowing about ball actions. To validate the players' scores on the TACSIS, regular trainers for three of the national youth soccer teams were asked to rate the tactical skills of each of 18 Dutch players on a 6-point Likert scale, ranging from 'Very poor' to 'Excellent'. The Spearman's correlation between the trainers' ratings and the players' TACSIS sum score was 0.79 , underlining the validity of the measure (Kannekens et al., 2009).

Table I. Items of the Tactical Skills Inventory for Sports (TACSIS; Elferink-Gemser et al., 2004).

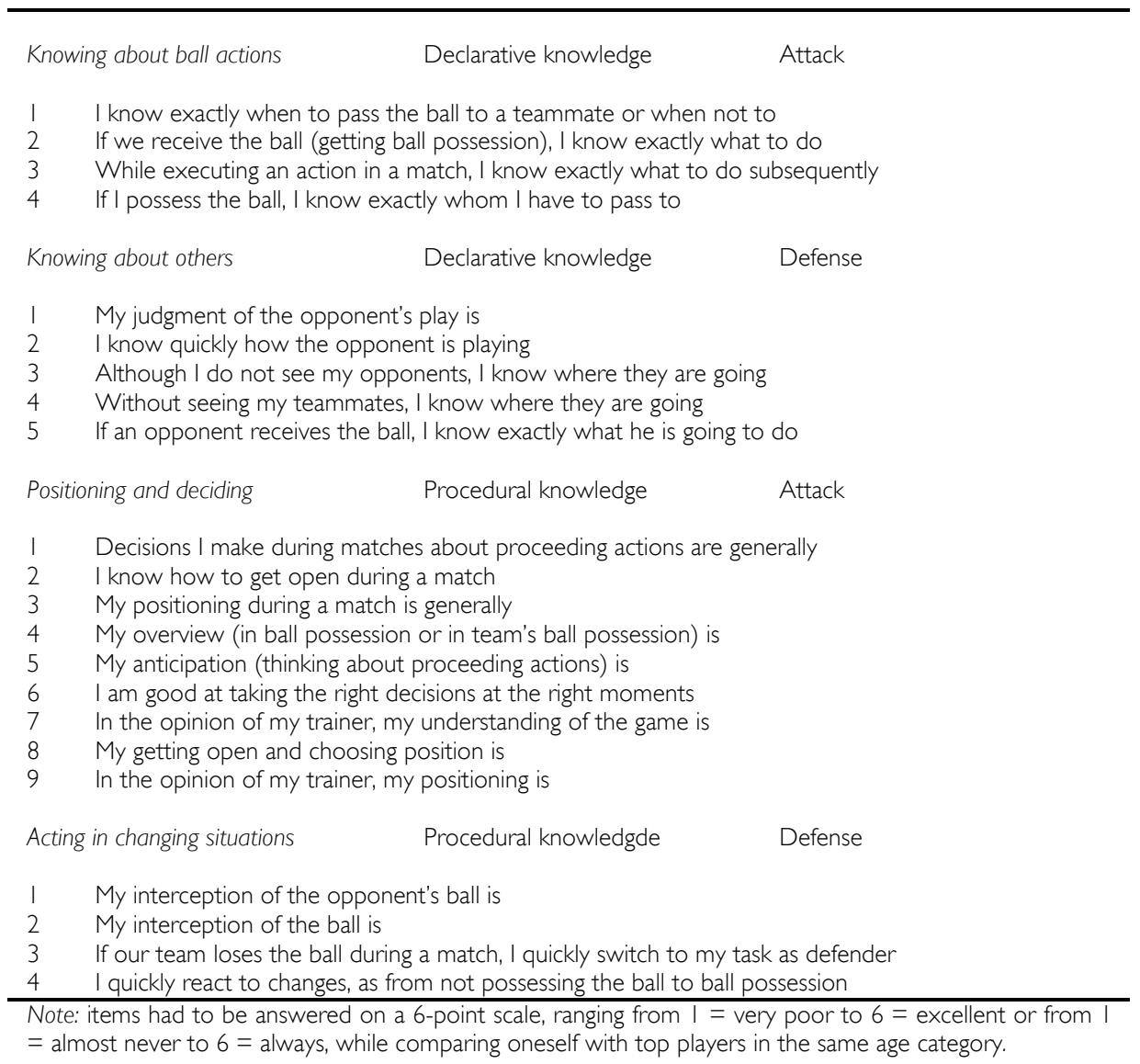

Being a self-report instrument, measures are susceptible to the individual's selfconfidence. Since confidence is associated with elite performance in various 
sports, this might affect the results obtained with such a measurement (Mahoney et al., 1987; Woodman and Hardy, 2003). Therefore, in terms of the validity of the TACSIS, it is important that players are at least 14 years of age or have experience of at least five years in invasion sports. In case the TACSIS is used with youth players, it is recommended that they play at a high level of performance. The TACSIS can be applied in youth players provided that the players have been confronted frequently with all aspects of their performance on the field. For example, in talented players, trainers, coaches, peers and parents give feedback on how fast they are, how well they dribble the ball and also whether or not they perform the right action at the right moment. When players are confronted by (significant) others about their tactical skills for many years, they ultimately develop knowledge of how good (or bad) they really are. In other words, regardless of their enhanced confidence, elite players are thought to have a realistic perspective of their tactical skills. The TACSIS is thus suitable for gathering data on tactical skills of experienced youth athletes in invasion sports. With the TACSIS, information can be gathered on 'knowing what to do' and 'doing it' in attacking as well as in defensive situations.

\section{CONCLUSION}

The knowlegde base on physical, physiological and technical components of performance in a variety of team sports is relatively rich. The influence of psychological skills on successful performance is also increasingly recognized. In contrast, tactical skills have been less studied even though these skills have are closely related to successful performance, especially in invasion sports. Although there are several ways to assess tactical skills, to date there is no standard measure. A measurement that is specifically designed for application in sports practice and that takes real-world settings into account is the Tactical Skills Inventory for Sports (TACSIS). The instrument is suitable for gathering data on tactical skills of experienced youth athletes participating in invasion sports. The TACSIS provides information on 'knowing what to do' and 'doing it' in attacking defensive situations. The tactical skills are related to positioning and deciding, knowing about ball actions, knowing about others and acting in changing situations.

\section{REFERENCES}

Ali A, Williams C, Hulse M, Strudwick A, Reddin J, Howarth L et al. (2007) Reliability and validity of two tests of soccer skill. Journal of Sports Sciences, 25 (| 3), | |46|-| 470. 
Allard F, Burnett N (1985) Skill in Sport. Canadian Journal of Psychology-Revue Canadienne de Psychologie, 39, 294-312.

Allard F, Deakin J, Parker S, Rodgers W (1993). Declarative knowledge in skilled motor performance: Byproduct or constituent? In JL Starkes, F Allard (Eds), Cognitive issues in motor expertise. Amsterdam: Elsevier Science Publishers BV, pp 95- 107.

Almond L (1986) Reflecting on theses: a games classification. In R Thorpe, D Bunker, L Almond (Eds), Rethinking games teaching. Loughborough, England: Loughborough University of Technology, pp 7I-72.

Baker J, Cote J, Abernethy B (2003a) Learning from the experts: practice activities of expert decision makers in sport. Research Quarterly for Exercise and Sport, 74, 342-347.

Baker J, Cote J, Abernethy B (2003b) Sport-specific practice and the development of expert decision-making in team ball sports. Journal of Applied Sport Psychology, 15, 12-25.

Bard C, Fleury M, Goulet C (1994) Relationship between perceptual strategies and response adequacy in sport situations. International Journal of Sport Psychology, 25, 266-28I.

Baxter-Jones A, Goldstein H, Helms P (1993) The development of aerobic power in young athletes. Journal of Applied Physiology, 75, I I 60- I 167.

Bjurwill C (1993) Read and react - The football formula. Perceptual and Motor Skills, 76, I 383-। 386.

Chamberlain CJ, Coelho AJ (1993) The Perceptual side of action: Decisionmaking in sport. In JL Starkes, F Allard (Eds), Cognitive Issues in Motor Expertise. Amsterdam: Elsevier Science Publishers BV, pp I35- 157.

Elferink-Gemser MT, Visscher C, Lemmink KAPM, Mulder Th (2004) Relation between multidimensional performance characteristics and level of performance in talented youth field hockey players. Journal of Sports Sciences, 22, 1053-1063.

Elferink-Gemser MT, Visscher C, Lemmink KAPM, \& Mulder Th (2007) Multidimensional performance characteristics and performance level in talented youth field hockey players: A longitudinal study. Journal of Sports Sciences, 25, 48I-489.

Elferink-Gemser MT, Visscher C, Van Duijn MAJ, Lemmink KAPM (2006) Development of the interval endurance capacity in elite and sub-elite youth field hockey players. British Journal of Sports Medicine, 40, 340-345.

Elferink-Gemser MT, Visscher C, Richart H, Lemmink KAPM (2004) Development of the tactical skills inventory for sports. Perceptual and Motor Skills, 99, 883-895.

Ericsson KA, Kintsch W (1995) Long-term working-memory. Psychological Review, 102, 21 I-245.

Ericsson KA, Simon HA (1980) Verbal reports as data. Psychological Review, 87, 2|5-25|. 
French KE. McPherson SL (1999) Adaptations in response selection processes used during sport competition with increasing age and expertise. International Journal of Sport Psychology, 30, 173- 193.

French KE, Nevett ME, Spurgeon JH, Graham KC, Rink JE, McPherson SL (1996) Knowledge representation and problem solution in expert and novice youth baseball players. Research Quarterly for Exercise and Sport, 67, 386-395.

French KE, Thomas JR (1987) The relation of knowledge development to children's basketball performance. Journal of Sport Psychology, 9, I5-32.

Gil S, Ruiz F, Irazusta A, Gil J, Irazusta J (2007) Selection of young soccer players in terms of anthropometric and physiological factors. Journal of Sports Medicine and Physical Fitness, 47, 25-32.

Grehaigne JF, Godbout P (1995) Tactical knowledge in team sports from a constructivist and cognitive perspective. Quest, 47, 490-505.

Grehaigne JF, Godbout P, Bouthier D (1999) The foundations of tactics and strategy in team sports. Journal of Teaching in Physical Education, 18, 159174

Grehaigne JF, Godbout P, Bouthier D (200I) The teaching and learning of decision making in team sports. Quest, 53, 59-76.

Hansen L, Bangsbo J, Twisk J, Klausen K (1999). Development of muscle strength in relation to training level and testosterone in young male soccer players. Journal of Applied Physiology, 87, I | 4 | - I 47.

Helsen WF, Starkes JL (1999) A multidimensional approach to skilled perception and performance in sport. Applied Cognitive Psychology, 13, I-27.

Hughes MD, Bartlett RM (2002) The use of performance indicators in performance analysis. Journal of Sports Sciences, 20, 739-754.

Huijgen BC, Elferink-Gemser MT, Post WJ, Visscher C (2009) Soccer skill development in professionals. International Journal of Sports Medicine.

Janelle CM, Hillman CH (2003) Expert performance in sport: Current perspectives and critical issues. In JL Starkes, KA Ericsson (Eds), Expert performance in sports: Advances in research on sport expertise. Champaign, IL: Human Kinetics, pp 49-83.

Jonker L, Elferink-Gemser MT, Visscher C (2009) Talented athletes and academic achievements: a comparison over 14 years. High Ability Studies, 20, 55-64.

Kannekens R, Elferink-Gemser MT, Visscher C (2009) Tactical skills of worldclass youth soccer teams. Journal of Sports Sciences, 27, 807-8I 2.

Kukolj M, Ugarkovic D, Jaric S (2003) Profiling anthropometric characteristics and functional performance of 12 to 18 -year-old elite junior soccer players. Journal of Human Movement Studies, 45, 403-4I 8.

Mahoney MJ, Gabriel TJ, Perkins TS (1987) Psychological skills and exceptional athletic performance. The Sport Psychologist, I, 181-199.

McMorris T, Graydon J (1997) The effect of exercise on cognitive performance in soccer-specific tests. Journal of Sports Sciences, 15, 459-468. 
McPherson SL (1994) The development of sport expertise - Mapping the tactical domain. Quest, 46, 223-240.

McPherson SL (1999) Expert-novice differences in performance skills and problem representations of youth and adults during tennis competition. Research Quarterly for Exercise and Sport, 70, 233-25I.

McPherson SL, Kernodle MW (2003) Tactics, the neglected attribute of expertise. Problem representations and performance skills in tennis. In JL Starkes, KA Ericsson (Eds), Expert Performance in Sports. Advances in Research on Sport Expertise. Champaign, IL: Human Kinetics, pp I 37- 67.

McPherson SL, Thomas JR (1989) Relation of knowledge and performance in boys' tennis - Age and expertise. Journal of Experimental Child Psychology, $48,190-211$.

Mitchell SA (1996) Tactical approaches to teaching games: improving invasion game performance. Journal of Physical Education, Recreation and Dance, 67(2), 30-33.

Mouchet A (2005) Subjectivity in the articulation between strategy and tactics in team sports: an example in rugby. Italian Journal of Sport Sciences, 12, 2433.

Nougier V, Rossi B (1999) The development of expertise in the orienting of attention. International Journal of Sport Psychology, 30, 246-260.

Nunnally JC, Bernstein IH (1994) Psychometric theory. New York: McGraw-Hill.

Oslin JL, Mitchell SA, Griffin LL (1998) The game performance assessment instrument (GPAl): Development and preliminary validation. Journal of Teaching in Physical Education, 17, 231-243.

Starkes JL (1987) Skill in field hockey - The nature of the cognitive advantage. Journal of Sport Psychology, 9, I46-160.

Thomas JR, French KE, Humphries CA (1986) Knowledge development and sport skill performance - Directions for motor behavior research. Journal of Sport Psychology, 8, 259-272.

Thomas JR, Nelson JK (1996) Research methods in physical activity. Champaign, IL Human Kinetics.

Vaeyens R, Malina RM, Janssens M, Van Renterghem B, Bourgois J, Vrijens J et al. (2006) A multidisciplinary selection model for youth soccer: the Ghent Youth Soccer Project. British Journal of Sports Medicine, 40, 928-934.

Visscher C, Elferink-Gemser MT, Lemmink KAPM (2006). Interval endurance capacity of talented youth soccer players. Perceptual and Motor Skills, 102, 8I-86.

Visscher C, Elferink-Gemser MT, Richart H, Lemmink, KAPM (2005)

Necessity of including tactical skills measurement in a field hockey talent development program. 1 $0^{\text {th }}$ Annual Congress of the European College of Sport Sciences (ECSS), Belgrade, Serbia, 187- 188.

Williams AM (2000) Perceptual skill in soccer: Implications for talent identification and development. Journal of Sports Sciences, 18, 737-750. 
Williams M, Davids K (1995) Declarative knowledge in sport - A by-product of experience or a characteristic of expertise. Journal of Sport \& Exercise Psychology, 17, 259-275.

Williams M, Davids K, Burwitz L, Williams J (1993) Cognitive knowledge and soccer performance. Perceptual and Motor Skills, 76, 579-593.

Williams AM, Davids K, Williams JG (1999) Visual perception and action in sport. London and New York: Taylor and Francis.

Woodman T, Hardy L (2003) The relative impact of cognitive anxiety and self-confidence upon sport performance: a meta-analysis. Journal of Sports Sciences, 21 , 443-457. 
Série

Investigação

Imprensa da Universidade de Coimbra

Coimbra University Press

2010

- U r

C • 